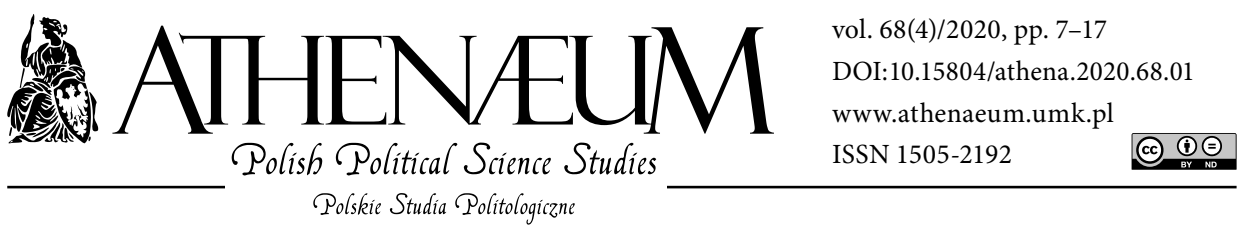

\title{
SOME REFLECTIONS ON THE THEORY OF HYBRID ACTIVITIES
}

\author{
KILKA REFLEKSJI NA TEMAT TEORII DZIAŁAŃ HYBRYDOWYCH
}

\author{
Benon Zbigniew Szałek*
}

\begin{abstract}
- ABSTRACT
This paper presents some remarks on the theory of hybrid activities. Analysis of relevant texts indicates that at present there is no real theory of hybrid activities. Interpretations and definitions of hybrid activities differ to some extent and certain important features are missing. For example, some authors opine that hybrid activities consist of simultaneous military and non-military operations. This opinion is not necessarily true as non-military activities can precede military activities. Monitoring this phase of hybrid activities is particularly important. The so-called "crisis management" covers (from the viewpoint of praxeology) a too narrow area.
\end{abstract}

Keywords: hybrid activities; hybrid warfare; nonmilitary activities; peace; politics

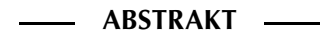

Niniejszy artykuł przedstawia kilka uwag na temat teorii działań hybrydowych. Analiza przedmiotowej literatury wskazuje, że obecnie nie ma czegoś takiego jak rzeczywista teoria działań hybrydowych. Interpretacje i definicje działań hybrydowych różnią się $\mathrm{w}$ pewnym stopniu, a niektóre istotne problemy nie są w ogóle poruszane. Na przykład niektórzy autorzy są zdania, że działania hybrydowe składają się z jednoczesnych militarnych i niemilitarnych operacji. Ta opinia jest niekoniecznie słuszna, jako że niemilitarne działania mogą poprzedzać działania militarne. Monitorowanie tej fazy działań hybrydowych jest szczególnie ważne. Tak zwane „zarządzanie kryzysowe" swoim obecnym zakresem pokrywa, z punktu widzenia prakseologii (nauki o korzystnym, sprawnym działaniu), zbyt wąski obszar działań.

Słowa kluczowe: działania hybrydowe; wojna hybrydowa; działania niemilitarne; pokój; polityka

* University of Szczecin, Faculty of Social Sciences. 


\section{INTRODUCTION - METHODOLOGY, DEFINITIONS AND RELATED PROBLEMS}

Methodology employed in this paper is based on system approach and a comparative analysis of relevant texts in English, Russian, and Polish.

The main questions are:

1. is there a convincing theory of hybrid activities?

2. what is missing in the hitherto existing interpretations of "hybrid activities"?

According to M.S. Vračar and M.T. Curčić: "the theory of 'hybrid warfare' was established in 2007" (Vračar \& Curčić, 2018). M. Caliskan follows this opinion: "It was Frank Hoffman who developed the hybrid warfare concept [...]" (Caliskan, 2019, p. 11).

In fact, the concept of hybrid war (conventional and unconventional activities) can be found in The Art of War, written by the Chinese strategist Sun Tzu around 500 BC (Sun Tzu, 1963; Szałek, 2017).

In 2007, F.G. Hoffman described hybrid threats as: "a range of different modes of warfare, including conventional capabilities, irregular tactics and formations, terrorist acts including indiscriminate violence and coercion and criminal disorder. Hybrid war can be conducted by both states and variety of non-state actors" (Hoffman, 2007, p. 14).

Individual interpretations, descriptions and definitions of "hybrid war", or "hybrid activities", vary (Szałek 2015a, 2016,2017). Some of them are very simple and general (for instance: military activities plus „extras”).

M. Wrzosek understands "hybrid war" as a complex of four kinds of threats: traditional (regular) threats, irregular threats, terrorism and information technology (Wrzosek, 2018, p. 318). According to M. Wrzosek, hybrid war is a kind of asymmetric conflict conducted in three dimensions: regular and irregular military activities, local psychological operations (psyops), and propaganda on the international scene - for instance trolling (Wrzosek, 2018, pp. 321-322).

On the other hand, S. Miracola sees a difference between asymmetric and hybrid warfare: "Unlike asymmetric warfare, which simply relies on the use of the so-called indirect approach - e.g., non-conventional means of war, such as terrorism, insurgency, and cyber warfare - hybrid warfare distinguishes itself for the simple fact that it envisages the multiple, simultaneous use of different types of operational systems, which range from the conventional to the unconventional spectrum" (Miracola, 2018, p. 2). In other words, S. Miracola sees a difference 
between asymmetric and hybrid warfare - unlike M. Wrzosek ("hybrid war is a kind of asymmetric conflict" - see above).

M.S. Vračar and M. Curčić emphasize the evolution of this concept: "Since the beginning of the Ukrainian crisis, the perception of the concept of 'hybrid warfare' has been considerably changing and expanding. In addition to violent methods, the concept has also included non-violent methods such as economic, diplomatic, political, information methods, etc." (Vračar \& Ćurčić, 2018, p. 5).

According to C.S. Chivvis: "Russia's Hybrid Warfare Toolkit" includes: information operations, cyber activities, proxies, economic influence, clandestine measures (traditional espionage, bribing, extorting), political influence. And C.S. Chivvis adds: "Behind these levers lies the implicit threat of Russian conventional and, in the extreme, nuclear force" (Chivvis, 2017, pp. 3-4).

According to M. Caliskan, European Union defines "hybrid threats" as a "mixture of coercive and subversive activity, conventional and non-conventional methods (i.e., diplomatic, military, economic, technological), which can be used in a coordinated manner by state or non-state actors to achieve specific objectives [...]" (Caliskan, 2019, p. 12).

F. Bekkers, R. Meessen and D. Lassche enhance the European interpretation of hybrid activities: "they are designed to be difficult to detect or attribute. These threats target critical vulnerabilities and seek to create confusion - to hinder swift and effective decision-making" (Bekkers, Meessen, \& Lassche, 2018, p. 7).

On the other hand, M. Caliskan, referring to the North Atlantic Treaty Organisation, deploys a wider spectrum of hybrid activities: "broad, complex, adaptive opportunistic and often integrated combinations of conventional and unconventional methods. These activities could be overt or covert, involving military, paramilitary, organized criminal networks and civilian actors across all elements of power" (Caliskan, 2019, p. 12).

The above examples direct our attention at such problems as: coordination/ integration/synchronization/simultaneity, involvement of civil and criminal sector (non-state actors).

F. Bekkers, R. Meessen, and D. Lassche emphasize the problem of the DIMEL (diplomatic, informational, military, economic, legal/law) instruments, and the PMESIIP (political, military, economic, social, infrastructural, information, physical environment) elements of the target country's society (Bekkers, Meessen, \& Lassche, 2018 , p. 8). They also pay some attention to:

1. vertical (intensity) and

2. horizontal (synchronization) escalation of hybrid activities. 


\section{CRITICISM OF THE CONCEPT}

M. Caliskan points out that: "there is an increasing number of critiques about the validity and the use of the concept" (Caliskan, 2019, p. 12). He presents 5 groups of objections: the concept of hybrid warfare is not new; it is a weak concept and its definitions are ambiguous; hybrid warfare creates an unnecessary category. Moreover, "hybrid warfare is about tactics (not strategy)", and "hybrid warfare is under the threshold of Article 5 [of NATO - B.Z.S.]" (Caliskan, 2019, p. 12).

However, there are researchers who regard the concept of hybrid warfare as a useful construct.

For instance, according to M. Weissmann: "It is found that [hybrid warfare - B.Z.S.] while being old wine in new bottles, it is still a good wine well worth drinking. While there is not much new in the concept itself, it is a useful tool to think about past wars, today's wars and the wars of the future" (Weissmann, 2019, p. 17).

According to P.R. Mansoor: "hybrid warfare is a useful construct to analyse conflicts involving regular and irregular forces engaged in both symmetric and asymmetric combat" (Mansoor, 2012, p. 3).

\section{TOWARD A CONVINCING THEORY OF HYBRID ACTIVITIES}

D. Fiott and R. Parkes point out that: "the use of the term 'hybrid threats' has been accompanied by some doubts about whether it actually means anything. [...] it is argued that the concept fails to provide a theory that is both comprehensive and operational, and those are precisely the qualities which strategists and policymakers demand from their theories" (Fiott \& Parkes, 2019, p. 4).

My impression is that there are problems with:

1. lack of common terminology and differing understanding of such concepts as "hybrid wars" (for instance: NATO - EU);

2. static enumerations of elements of hybrid instrumentarium and activities (for instance: propaganda, manipulations, agents of influence, etc.);

3. disintegrated analysis of specific kinds of hybrid activities - instead of a holistic/integrated approach;

4. aggressive propaganda in favour of unproven concepts, such as for example an Eurasiatic political structure to be conducted by Russia (Dugin, 1997; Mikołajec, 2000; Wojnowski, 2014; Szałek, 2015; Sykulski, 2019). Economic data clearly illustrate the fact that Russian leaders are unable to 
govern efficiently their own, huge country (for example, Gross Domestic Product of Italy was in 2016 bigger than Gross Domestic Product of Russia; Italy 1850 bn USD : Russia 1283 bn USD) (Rocznik..., 2017, p. 878). Another example of unproven concepts offers the so-called Multi-level Governance in the European Union: G. Marks promises that transfer of power from the governmental level up to the level of the European Commission, and down to the subnational level (regions, etc.) will improve the efficiency of governance in the European Union to a considerable extent (Marks, 1993; Hooghe \& Marks, 2004; Szałek, 2013);

5. depersonalization (for instance, assumption that government $=$ state/ country).

\section{WHAT IS MISSING?}

The term "hybrid war" implies dynamics. It is necessary to move from static and asymmetric (offensive) "descriptions" of hybrid activities to dynamic and symmetric (offensive and defensive; aggressors : defenders) description of hybrid activities.

These problems can be illustrated by means of some simple models.

Model 1:0; presents offensive hybrid activities conducted by one centre/ party against another; attention is being paid to the aggressor - the response of the party under attack is neglected.

Variant 1:0 (a); chaotic hybrid activities (lack of coordination).

Variant 1:0 (b); coordinated (synchronized, etc.) hybrid activities.

Model $1: 1$; comprises two centres conducting hybrid activities. Attention is being paid to the spectrum of their hybrid activities, their potential, differentiation, etc.

Variant $1: 1$ (a); both sides/parties conduct chaotic hybrid activities.

Variant $1: 1$ (b); the aggressor conducts coordinated (integrated, etc.) hybrid activities - the defender conducts chaotic hybrid activities.

Variant 1:1 (c); the aggressor conducts chaotic hybrid activities, the defender conducts coordinated (integrated) hybrid activities.

Variant 1:1 (d); the aggressor as well as the defender conduct coordinated (integrated) hybrid activities.

Model $1+\mathrm{X}: 1$; the attacking party has some allies, whereas the party under attack fights alone. 
Variant $1+\mathrm{X}: 1$ (a); the allied aggressors conduct coordinated hybrid activities, whereas the attacked party conducts chaotic hybrid activities.

Variant $1+\mathrm{X}: 1$ (b); both sides of the conflict conduct chaotic, uncoordinated hybrid activities.

Variant $1+\mathrm{X}: 1$ (c); the allied aggressors conduct chaotic hybrid activities, whereas the defenders conduct coordinated hybrid activities.

Variant $1+\mathrm{X}: 1$ (d); both sides of the conflict conduct coordinated hybrid activities.

Model $1+\mathrm{X}: 1+\mathrm{Y}$; both sides of the conflict have allies.

Variant $1+\mathrm{X}: 1+\mathrm{Y}(\mathrm{a})$; the allied aggressors conduct coordinated hybrid activities, whereas the defenders conduct chaotic hybrid activities.

Variant $1+\mathrm{X}: 1+\mathrm{Y}(\mathrm{b})$; both sides of the conflict conduct chaotic hybrid activities.

Variant $1+\mathrm{X}: 1+\mathrm{Y}(\mathrm{c})$; the allied aggressors conduct chaotic hybrid activities, whereas the defenders conduct coordinated hybrid activities.

Variant $1+\mathrm{X}: 1+\mathrm{Y}(\mathrm{d})$; both sides conduct coordinated hybrid activities.

Of course, these models and their variants must be equipped with all necessary data concerning, for instance, their symmetry/asymmetry with regard to the spectrum of their activities, their potential, problems, effectiveness.

Moreover, these models/variants must take into account all kinds of specific feedbacks (e.g.: aggressors - defenders; positive and negative feedbacks) and the changing situation.

\section{WAR AND PEACE}

In 2007, M. Bond (USA) presented her interpretation of "hybrid war" as "ranging from purely peaceful humanitarian missions as preventive measures, [...] through traditional warfighting operations [...] to post conflict reconstructions and stabilization efforts [...]" (Bond, 2007, p. 4). This clear sequence of activities (peace $>$ war $>$ peace) widens the spectrum of activities to some extent. It is not so destructive as the interpretation of hybrid war as "military activities" and "extras".

Let us pay some attention to the relationship: peace $>$ war.

According to Sun Tzu, a Chinese strategist (c. 500 BC): “Generally in war the best policy is to take a state intact; to ruin it is inferior to this" (Sun Tzu, 1963, 
p. 77). His opinion was not shared by C. von Clausewitz (1780-1831), a Prussian strategist (Clausewitz, 1984). C. von Clausewitz regarded war as continuation of politics - but with different means.

According to R. McDermott, "hybrid war" means "blurring of war and peace" (McDermott, 2014, p. 2).

F. Bekkers, R. Meessen and D. Lassche pay some attention to such techniques of hybrid warfare as blurring and blending (when peace becomes war?) (Bekkers, Meessen, \& Lassche, 2018, p. 8).

S. Miracola speaks of "blurry areas [of hybrid war - B.Z.S.] where it becomes increasingly difficult to distinguish peacetime from wartime operations and vice versa" (Miracola, 2018, p. 2).

According to M. Caliskan, "hybrid activities" are conducted "to achieve specific objectives [...] while remaining below the threshold of formally declared warfare (Caliskan, 2019, p. 12).

According to some researchers, the concept of hybrid war is based on simultaneity of military and non-military (political, diplomatic, economic, medial, etc.) activities (Vračar \& Curčić, 2018, p. 5; Miracola, 2018, p. 2).

For example, S. Miracola opines that: "hybrid warfare distinguishes itself for the simple fact that it envisages the multiple, simultaneous use of different types of operational systems which range from the conventional to the unconventional spectrum. The key word that defines it at the operational and strategic level is 'simultaneity"' (Miracola, 2018, p. 2).

The question is: is this (military + non-military) simultaneity a condition sine qua non?

Hostile, Janus-like, non-military activities, preceding the hostile military activities can cause considerable damage, comparable to the damage inflicted by rockets and bombs.

The Janus-like (short-term, long-term) hostilities may be hard to notice (they may be hidden below the threshold of formally declared warfare), yet they can be regarded as combined, coordinated preparations for military hostile activities.

Let us illustrate this problem with some examples (Bernays, 1928; Volkoff, 1986; Bäcker, 2007; Friedman, 2009, 2011; Mazur, 2010; Song Hongbing, 2010; Hayes, 2012; Brzeziński, 2012; Sydow, 2013; Lubowski, 2013; Karwat, 2014; Minkina, 2014; Szałek, 2013b, 2015b, 2018; Szewczak, 2016; Ham, 2016; Wojtaszak, Jartyś, \& Krawcewicz, 2016; Freedman, 2017; Wrzosek, 2018; Piątek, 2019):

1. overt and covert state and non-state networks (e.g., hostile civil society organizations, secret service networks, networks of agents of influence, 
networks of hostile religious/"educational" institutions, hostile networks of "charities", overt and covert hostile alliances, ambiguous alliances (> hostile false allies), hostile medial activities, financial/trade networks (transnational networks of corporations), drug networks,

2. hostile social engineering (e.g., instigating emigration and hostile immigration), hostile cryptocracy,

3. hostile currency, economic, financial, trade activities,

4. hostile energy activities (monopolization of energy supplies, i.e., no diversification), energy supplies from hostile state and non-state actors,

5. hostile creation of "knowledge"/space of illusions, hostile political correctness, hostile historical policy, hostile religious/ethnic correctness, covert fake news (misinformation, disinformation, fake "forecasting"), hostile engineering of the future, manipulation (e.g., using the Overton window of political possibilities), propaganda,

6. "chameleons" in secret services, politics, science, religion, literature, journalism,

7. incessant and orchestrated psychological operations (for example, sense of guilt),

8. public/international humiliations,

9. hostile activities in cyberspace (hacking, trolling, blockades, etc.),

10. hostile decisions concerning epidemics, ecology,

11. hostile decisions concerning military purchases, military potential and personnel,

12. hostile decisions regarding stocks,

13. wrong attitude towards terrorism.

\section{CONCLUSION}

The above analysis indicates that at present there is no convincing theory of "hybrid war/warfare/activities (lack of common terminology, contradictory/ differing definitions).

Static enumerations of hybrid instrumentarium are expected to describe dynamic hybrid activities.

Disintegrated analyses of specific kinds of hybrid activities are meant to represent the real situation. 
The problem of simultaneity of hybrid non-military activities preceding the phase of military activities is practically missing: what can be regarded as the "beginning of war"?

There are other missing/neglected issues. For example: the threshold of formally declared warfare (hybrid war - hybrid activities), Janus-like hostile activities, optimal hybrid activities mix, crisis management - dealing (e.g., monitoring) with hostile hybrid activities/threats preceding the phase of military hybrid activities $>$ war.

The above remarks suggest a need for integrated, permanent, complex (catchall) attention with regard to the development of hybrid threats and adequate counter-measures.

\section{REFERENCES:}

Bäcker, R. (2007). Rosyjskie myślenie polityczne za czasów prezydenta Putina. Toruń: Wyd. Adam Marszałek.

Bekkers, F., Meessen, R., \& Lassche, D. (2018, December). Hybrid Conflicts: The New Normal? The Hague: TNO Innovation for Life; The Hague Centre for Strategic Studies. Retrieved from: https://hcss.nl/sites/default/files/files/reports/Hybrid\%20conflicts.\%20The\%20New\%20Normal\%20-\%20HCSS\%20\%20TNO\%20\%281901\%29_0. pdf.

Bernays, E. (1928). Propaganda. New York: Horace Liveright.

Bond, M. (2007). Hybrid War: A New Paradigm for Stability Operations in Failing States. Carlisle, PA: US Army War College.

Brzeziński, Z. (2012). Strategic Vision: America and the Crisis of Global Power. New York: Hachette Book Group USA.

Caliskan, M. (2019, April 25). Hybrid Warfare and Strategic Theory. Beyond the Horizon ISSG. Retrieved from: https://www.behorizon.org/hybrid-warfare-through-the-lensof-strategic-theory/.

Chivvis, C.S. (2017, March 22). Understanding Russian „Hybrid Warfare” and What Can Be Done about It. Testimony Presented before the House Armed Services Committee. Santa Monica, CA: The Rand Corporation. Retrieved from: https://www.rand.org/ content/dam/rand/pubs/testimonies/CT400/CT468/RAND_CT468.pdf.

Clausewitz, C. von (1984). On War. Eds. and transl. M.E. Howard, \& P. Paret. Princeton, NJ: Princeton University Press.

Dugin, A. (1997). Osnowy geopolitiki: Geopoliticzeskoje buduszczeje Rossii. Moskwa: Arktogeja-Center.

Fiott, D., \& Parkes, R. (2019, April). Protecting Europe. The EU's Response to Hybrid Threats. Chaillot Paper, 151. Paris: European Union Institute for Security Studies. 
Retrieved from: https://espas.secure.europarl.europa.eu/orbis/sites/default/files/ generated/document/en/CP_151.pdf.

Freedman, L. (2017). The Future of War: A History. London: Penguin Books.

Friedman, G. (2009). The Next 100 Years: A Forecast for the 21 $1^{\text {st }}$ Century. New York: Doubleday Books.

Friedman, G. (2011). The Next Decade: What the World Will Look Like. New York: Doubleday Books.

Ham, P.van (2016, February). Brexit: Strategic Consequences for Europe: A Scenario Study. The Hague: Clingendael - Netherlands Institute of International Relations. Retrieved from: https://www.clingendael.org/sites/default/files/pdfs/Brexit\%20Report\%20 February\%202016.pdf.

Hayes, B. (2012). Counter-Terrorism, "Policy Laundering," and the FATF: Legalizing Surveillance, Regulating Civil Society. Amsterdam: Transnational Institute/Statewatch.

Hoffman, F.G. (2007, December). Conflict in the $21^{\text {st }}$ Century: The Rise of Hybrid Wars. Arlington: Potomac Institute for Policy Studies. Retrieved from: https://www.potomacinstitute.org/images/stories/publications/potomac_hybridwar_0108.pdf.

Hooghe, L., \& Marks, G. (2004). Contrasting Visions of Multi-Level Governance. In: I. Bache, \& M. Flinders (eds.). Multi-Level Governance (pp. 15-30) Oxford: Oxford University Press.

Karwat, M. (2014). Podstawy socjotechniki dla politologów i nie tylko. Warszawa: Difin. Lubowski, A. (2013). Świat 2040. Czy Zachód musi przegrać? Kraków: Znak.

Mansoor, P.R. (2012). Hybrid Warfare in History. In: W. Murray, \& P.R. Mansoor (eds.). Hybrid Warfare: Fighting Complex Opponents from the Ancient World to the Present (pp. 1-10). New York: Cambridge University Press.

Marks, G. (1993). Structural Policy and Multilevel Governance in the EC. In: A. Cafruny, \& G. Rosenthal (eds.). The State of the European Community (pp. 391-410). Boulder: Lynne Rienner.

Mazur, W. (2010). Nie trzeba armat, żeby zająć cudzą ziemię. Nasza Polska, 30, 6.

McDermott, R. (2014). Myth and Reality - A Net Assessment of Russia's 'Hybrid Warfare' Strategy Since the Start of 2014 (Parts 1\&2). Eurasia Daily Monitor, 111(184-185).

Mikołajec, J. (2000). Drogi i bezdroża współczesnej polityki rosyjskiej na przykładzie nacjonalistycznych poglądów Aleksandra Dugina. Humanistyka i Przyrodoznawstwo, 6, 167-176.

Minkina, M. (2014). Sztuka wywiadu w państwie współczesnym. Warszawa: Oficyna Wydawnicza Rytm.

Miracola, S. (2018, December 21). Chinese Hybrid Warfare. Italian Institute for International Political Studies. Retrieved from: https:/www.ispionline.it/en/pubblicazione/ chinese-hybrid-warfare-21853.

Piątek, J. (2019). NIE: państwo, wojna, bezpieczeństwo. Toruń: Wyd. Adam Marszałek.

Poskitt, A., \& Dufranc, M. (2011). Civil Society Organizations in Situations of Conflict. Open Forum for CSO Development Effectiveness. CIVICUS: World Alliance for Citizen Participation.

Rocznik Statystyczny Rzeczypospolitej Polskiej (2017).Warszawa: GUS. 
Song Hongbin (2010). Wojna o pieniądz. Prawdziwe źródła kryzysów finansowych. Kobierzyce: Wektory.

Sykulski, L. (2019). Rosyjska geopolityka a wojna informacyjna. Warszawa: PIW. Sun Tzu (1963). The Art of War. Ed. S. Griffith. London: Oxford University Press.

Sydow, E. von (2013). Civil Society and Democracy: The Citizen's Shortcut to the EU. European Economic and Social Committee, Brussels: Visits and Publications Unit.

Szałek, B.Z. (2013a). Problem wielopoziomowego zarządzania (Multi-level Governance) w Unii Europejskiej w świetle prakseologii i heurystyki. In: J. Ruszkowski, \& L. Wojnicz (eds.). Multilevel Governance w Unii Europejskiej (pp. 61-86). Szczecin-Warszawa: Volumina.

Szałek, B.Z. (2013b). Some Praxiological Reflections on the So-called "Overton Window of Political Possibilities", "Framing" and Related Problems. Reality of Politics, 4, 237-257.

Szałek, B.Z. (2015a). Geopolitics, Political Topology and Hybrid Warfare. Reality of Politics, 6, 86-97.

Szałek, B.Z. (2015b). Kilka prakseologicznych uwag na temat globalnych wyzwań w kontekście Polski. In: R. Podgórzańska, \& J. Ruszkowski (eds.). Teoria i praktyka polityki (pp. 97-116). Szczecin: WN Minerwa.

Szałek, B.Z. (2016). The Blurred Problem of Foreign Funding of Civil Society Organizations in the Light of Political Marketing, Praxiology and Hybrid Warfare. Reality of Politics, 7, 195-211. DOI: 10.15804/rop201613.

Szałek, B.Z. (2017). The Common Security and Defence Policy of the European Union - in the Context of "Hybrid Warfare", "Networks", "Swarming" and "Consolidated Hybrid Defence". Reality of Politics, 8, 125-140. DOI: 10.15804/rop201708.

Szałek, B.Z. (2018). Some Praxiological Reflections on the Reliability of Political Forecasting. Reality of Politics, 9, 137-149. DOI: 10.15804/rop201810.

Szewczak, J. (2016). Banksterzy. Kulisy globalnej zmowy. Kraków: Biały Kruk.

Volkoff, V. (ed.). (1986). La désinformation: arme de guerre. Paris-Lausanne: Julliard-L'Age d'Homme.

Vračar, M.S., \& Curčić, M. (2018). The Evolution of European Perception of the Term "Hybrid War". Vojno Delo, 70(1), 5-21. DOI: 10.5937/vojdelo1801005V.

Weissmann, M. (2019). Hybrid warfare and hybrid threats today and tomorrow: towards an analytical framework. Journal on Baltic Security, 5(1), 17-26. DOI: 10.2478/jobs2019-0002.

Wojnowski, M. (2014). Aleksandr Dugin a resorty siłowe Federacji Rosyjskiej. Przyczynek do badań nad wykorzystaniem geopolityki przez cywilne i wojskowe służby specjalne we współczesnej Rosji. Przegląd Bezpieczeństwa Wewnętrznego, 10(14), 11-37.

Wojtaszak, J., Jartyś, A., \& Krawcewicz, A. (eds.). (2016). Europa wobec problemu uchodźców w XXI wieku. Szczecin: WN Minerwa.

Wrzosek, M. (2018). Wojny przyszłości. Doktryna, technika, operacje militarne. Warszawa: Fronda. 